\title{
A New Homo-Hexamer Mn-Containing Catalase from Geobacillus sp. WCH70
}

\author{
Hai-Chao Li ${ }^{1}$, Qing Yu ${ }^{1}$, Hui Wang ${ }^{1}$, Xin-Yu Cao ${ }^{1}$, Li Ma ${ }^{1,2, *}$ and Zheng-Qiang Li ${ }^{1, *}$ \\ 1 Key Laboratory for Molecular Enzymology \& Engineering, the Ministry of Education, School of Life Sciences, \\ Jilin University, 2699 Qianjin Street, Changchun 130012, Jilin, China; lhc14@mails.jlu.edu.cn (H.-C.L.); \\ 15043113677@163.com (Q.Y.); huiwang15@mails.jlu.edu.cn (H.W.); 18346661052@163.com (X.-Y.C.) \\ 2 Department of Physics, Georgia Southern University, Statesboro, GA 30460, USA \\ * $\quad$ Correspondence: lma@georgiasouthern.edu (L.M.); lzq@jlu.edu.cn (Z.-Q.L.); \\ Tel.: +86-0431-85155201 (Z.-Q.L.)
}

Received: 2 August 2017; Accepted: 12 September 2017; Published: 18 September 2017

\begin{abstract}
Catalase is an effective biocatalyst to degrade hydrogen peroxide to water and oxygen that can serve in textile effluent treatment to remove residual $\mathrm{H}_{2} \mathrm{O}_{2}$. Thermostable catalases are needed to withstand both the high temperature and $\mathrm{pH}$ of textile wastewater. We have cloned the Mn-containing catalase gene ACS24898.1 from Geobacillus sp. WCH70, which originated from thermophilic organisms, and expressed it in Escherichia coli in activated form. The recombinant protein has been purified to homogeneity and identified to be a new homo-hexamer Mn-containing catalase. The native molecular mass of the catalase has been measured to be $138 \mathrm{kDa}$ by size-exclusion chromatography. The new enzyme has optimum catalyzed activity at $\mathrm{pH} 9.0$ and a temperature of $75{ }^{\circ} \mathrm{C}$. It is thermostable up to $70{ }^{\circ} \mathrm{C}$ for $8 \mathrm{~h}$ incubation and maintains $80 \%$ and $50 \%$ activity, respectively, at $80^{\circ} \mathrm{C}$ after $5 \mathrm{~h}$ and $90^{\circ} \mathrm{C}$ after $1 \mathrm{~h}$. At $75^{\circ} \mathrm{C}$ and $\mathrm{pH} 9.0$, the $K_{m}$ is $67.26 \mathrm{mM}$ for substrate $\mathrm{H}_{2} \mathrm{O}_{2}$ and the rate of reaction at $\mathrm{H}_{2} \mathrm{O}_{2}$ saturation, $V_{\text {max }}$, is $75,300 \mathrm{U} / \mathrm{mg}$. The thermophilic and alkaline preferred properties of this new Mn-catalase are valuable features in textile wastewater treatment.
\end{abstract}

Keywords: Mn-containing catalase; homo-hexamer; Geobacillus sp. WCH70; alkaline; thermophilic; textile wastewater

\section{Introduction}

Enzyme catalase (EC 1.11.1.6) mostly exists in aerobic living organisms. Its main function is to catalytically decompose hydrogen peroxide $\left(\mathrm{H}_{2} \mathrm{O}_{2}\right)$ to water and oxygen in order to protect the cells from oxidative challenging by over-produced $\mathrm{H}_{2} \mathrm{O}_{2}$ [1,2]. Catalases also have potential to be industrial enzymes in environmental protection for removing $\mathrm{H}_{2} \mathrm{O}_{2}$ containing effluents [3,4]. $\mathrm{H}_{2} \mathrm{O}_{2}$ is commonly used as a powerful oxidant in the paper, food, and textile industries [5]. In the textile industry, $\mathrm{H}_{2} \mathrm{O}_{2}$ is widely used for bleaching. It is essential to remove the residual $\mathrm{H}_{2} \mathrm{O}_{2}$ from industrial waste after the reactions. Traditionally, the removal of residual $\mathrm{H}_{2} \mathrm{O}_{2}$ can be done by extensive washing (100 $\mathrm{L}$ of water $/ 1 \mathrm{~kg}$ of textiles) or using chemicals in the textile industry, which could cause further downstream problems [6]. Tzanov et al. first investigated dyeing in catalase-treated bleaching baths [7]. Catalase could be an effective biocatalyst to degrade $\mathrm{H}_{2} \mathrm{O}_{2}$ compared with chemical catalysts [8]. However, common catalases are favorably active at moderate temperatures below $50{ }^{\circ} \mathrm{C}$ and atneutral pHs, which limits their application in harsh conditions. For example, in the textile bleaching industry, the wastewater temperature could be more than $60^{\circ} \mathrm{C}$ [9]. There is need for thermostable catalases as industrial enzymes in the application of removing $\mathrm{H}_{2} \mathrm{O}_{2}$ from waste. One of the approaches will be to discover thermostable catalases from natural sources and to express them in expressing host cells. 
Typically catalases are classified as monofunctional heme-containing, bifunctional heme-containing peroxidases-like, and non-heme Mn-containing catalases [10,11]. Heme-containing catalases are widely spread in eukaryotes, bacteria, archaebacteria, and fungi $[10,12]$. The reaction of heme-containing catalase to degrade $\mathrm{H}_{2} \mathrm{O}_{2}$ is as follows [13]:

$$
\begin{gathered}
\mathrm{H}_{2} \mathrm{O}_{2}+\text { Enz }\left(\text { Por-Fe }^{\mathrm{III}}\right) \rightarrow \mathrm{H}_{2} \mathrm{O}+\mathrm{Cpd} \mathrm{I}\left(\text { Por }^{+}-\mathrm{Fe}^{\mathrm{IV}}=\mathrm{O}\right) \\
\mathrm{H}_{2} \mathrm{O}_{2}+\text { Cpd I }\left(\text { Por }^{+}-\mathrm{Fe}^{\mathrm{IV}}=\mathrm{O}\right) \rightarrow \mathrm{H}_{2} \mathrm{O}+\text { Enz }\left(\text { Por-Fe }^{\mathrm{III}}\right)+\mathrm{O}_{2}
\end{gathered}
$$

Few monofunctional catalases and bifunctional catalase-peroxidases have been reported to be thermostable so far [14-17]. Therefore, most heme-containing catalases are thermolabile proteins. The active center in a heme catalase is a mononuclear iron porphyrin, regardless of whether it is a mono- or bifunctional one. Unlike heme-containing catalases, Mn-containing catalases have a binuclear manganese complex in a catalytic active center to involve a two-electron oxidation-reduction cycle during turnover. The oxidation state of the dimanganese cluster is transformed between the $\mathrm{Mn}^{\mathrm{II}}-\mathrm{Mn}^{\mathrm{II}}$ and $\mathrm{Mn}^{\mathrm{III}}-\mathrm{Mn}^{\mathrm{III}}$ when reacting with $\mathrm{H}_{2} \mathrm{O}_{2}$. The $\mathrm{H}_{2} \mathrm{O}_{2}$ serves as an oxidant when a $\mathrm{Mn}^{\mathrm{II}}-\mathrm{Mn}^{\mathrm{II}}$ state exists (Equation (3)), and the $\mathrm{H}_{2} \mathrm{O}_{2}$ serves as a reductant when a $\mathrm{Mn}^{\mathrm{III}}-\mathrm{Mn}^{\mathrm{III}}$ state exists (Equation (4)) [10].

$$
\begin{gathered}
\mathrm{H}_{2} \mathrm{O}_{2}+\mathrm{Mn}^{\mathrm{II}}-\mathrm{Mn}^{\mathrm{II}}\left(2 \mathrm{H}^{+}\right) \rightarrow 2 \mathrm{H}_{2} \mathrm{O}+\mathrm{Mn}^{\mathrm{III}}-\mathrm{Mn}^{\mathrm{III}} \\
\mathrm{H}_{2} \mathrm{O}_{2}+\mathrm{Mn}^{\mathrm{III}}-\mathrm{Mn}^{\mathrm{III}} \rightarrow \mathrm{O}_{2}+\mathrm{Mn}^{\mathrm{II}}-\mathrm{Mn}^{\mathrm{II}}\left(2 \mathrm{H}^{+}\right)
\end{gathered}
$$

Until now, all Mn-containing catalases have existed in prokaryotes and archaea [18]. The class of Mn-containing catalases has several features that distinguish it from the class of heme-containing catalases. First, its four-helix bundle protein architecture makes Mn-catalase robust and stable at elevated temperatures [18]. Second, the catalase is relatively sensitive to low $\mathrm{H}_{2} \mathrm{O}_{2}$ concentrations because its intermediate reaction is more stable than that in heme-contaning catalases during turnover [18]. Third, Mn-catalase is not sensitive to cyanide inhibition of activity [18].

More than one hundred manganese catalase genes have been submitted to GenBank so far [18]. However, there are only seven Mn-containing catalases that have been purified and characterized. These enzyme genes come from either thermophilic bacteria or archaea. They are Lactobacillus plantarum (LPC) [19], Thermus thermophiles (TTC) [20], Thermus sp. YS 8-13 [21], Thermoleophilum album [22], Pyrobaculum caldifontis VA1 [23], Anabaena PCC7120 (KatB) [24], and Thermomicrobium roseum [25]. Purification of the Mn-containing catalases is difficult because the expression level of wild-type catalase is very low. Hence people often clone the target gene into other host cells; for example, Escherichia coli [16], Bacillus subtilis [26], Pichia pastoris [27], Hansenula polymorpha [28], and Lactococcus lactis [29]. Escherichia coli is the most popular host strain for the mature cloning and expression system in which the enzyme can be reproduced quickly and operated easily, but not all the thermophilic catalases can be expressed in activated soluble form [30].

In the present work, we have successfully cloned ACS24898.1, a Mn-containing catalase gene, from Geobacillus sp. WCH70 and expressed it in Escherichia coli in activated form. Geobacillus sp. WCH70 is a novel thermophilic, rod-shaped, Gram-positive facultative anaerobe, for which the optimum growth temperature is $70^{\circ} \mathrm{C}$ and the maximum growth temperature is $80^{\circ} \mathrm{C}$ [31]. The purified recombinant protein has been proved to be a new homo-hexamer manganese catalase. We name the new catalase GWC (Geobacillus sp. WCH70 catalase). Our results show that GWC is thermostable and has optimal activity at $\mathrm{pH} 9.0$ and a temperature of $75^{\circ} \mathrm{C}$. Finally, the kinetic parameters of $K_{m}$ and $V_{\max }$ of this new catalase are reported. 


\section{Results}

\subsection{DNA Sequence and Phylogenetic Analysis of ACS24898.1}

The total length of gene sequence ACS24898.1 is $570 \mathrm{bp}$, and the encoded protein contains 189 amino acids from NCBI (National Center for Biotechnology Information) GenBank. The protein sequences of selected manganese catalases from bacterial or archaea are obtained from PeroxiBase. The phylogenetic tree in Figure 1 is from an analysis in MEGA 7.0.25 using the neighbor-joining (NJ) method with 1000 bootstrap replications. The tree indicates the inferred evolutionary relationships among parts of the known Mn-catalase genes. The manganese catalases of Thermus thermophiles (TTC) and Lactobacillus plantarum (LPC) belong to two deeply rooted clades [18]. Figure 1 shows that the catalase of Geobacillus sp. WCH70 (GWC) has a distant relationship with both TTC and LPC. GWC shares its closest phylogenetic relationship with the manganese catalase of Heliobacterium modesticaldum (GenBank: ABZ83254.1), which possesses 190 amino acids. Unfortunately, the Heliobacterium modesticaldum catalase has not been purified and characterized. Figure 2 shows the comparison of the protein sequence of GWC with TTC, LPC, and Heliobacterium modesticaldum catalase. The protein sequence of GWC is most similar to that of Heliobacterium modesticaldum, which shares $62 \%$ sequence identity. However, GWC shares 34\% and 25\% identity with LPC and TTC, respectively. The ion binding amino acids of ACS24898.1 are Glu35, Glu64, His67, Glu135, and His168, which are as conservative as the other three manganese catalase sequences.

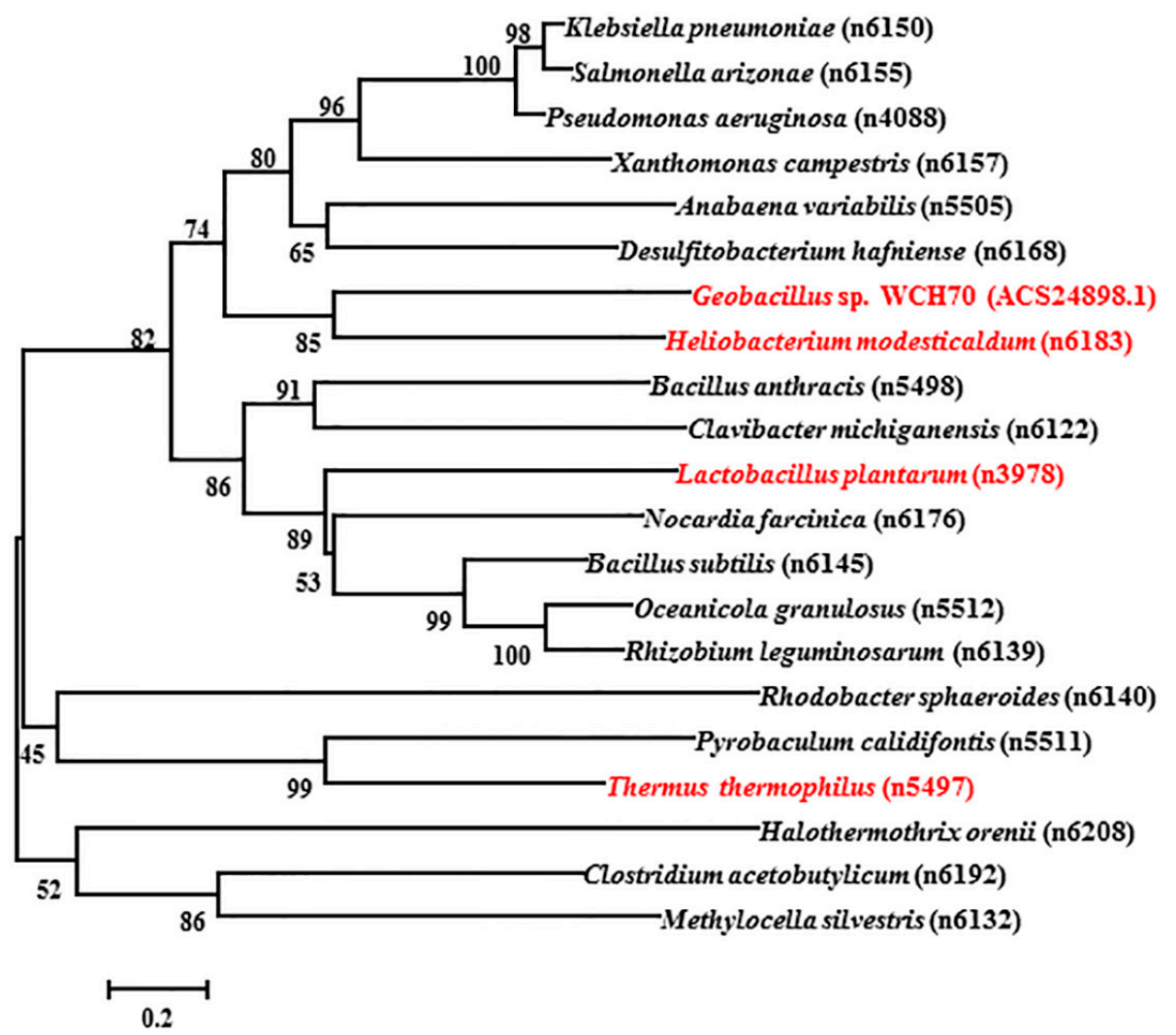

Figure 1. Phylogenetic tree of the species of new GWC (Geobacillus sp. WCH70 catalase) and 20 related Mn-catalases. The tree is constructed by the neighbor-joining method based on the amino acid sequences of the catalases obtained from PeroxiBase. The test of inferred phylogeny is a bootstrap for 1000 replications. Catalases from Geobacillus sp. WCH70 (ACS24898.1), Heliobacterium modesticaldum (n6183), Lactobacillus plantarum (n3978), and Thermus thermophiles (n5497) are marked in red. The relationships between GWC and the species for other three Mn-catalases range from close to far as n6183 > n3978 > n5497. 


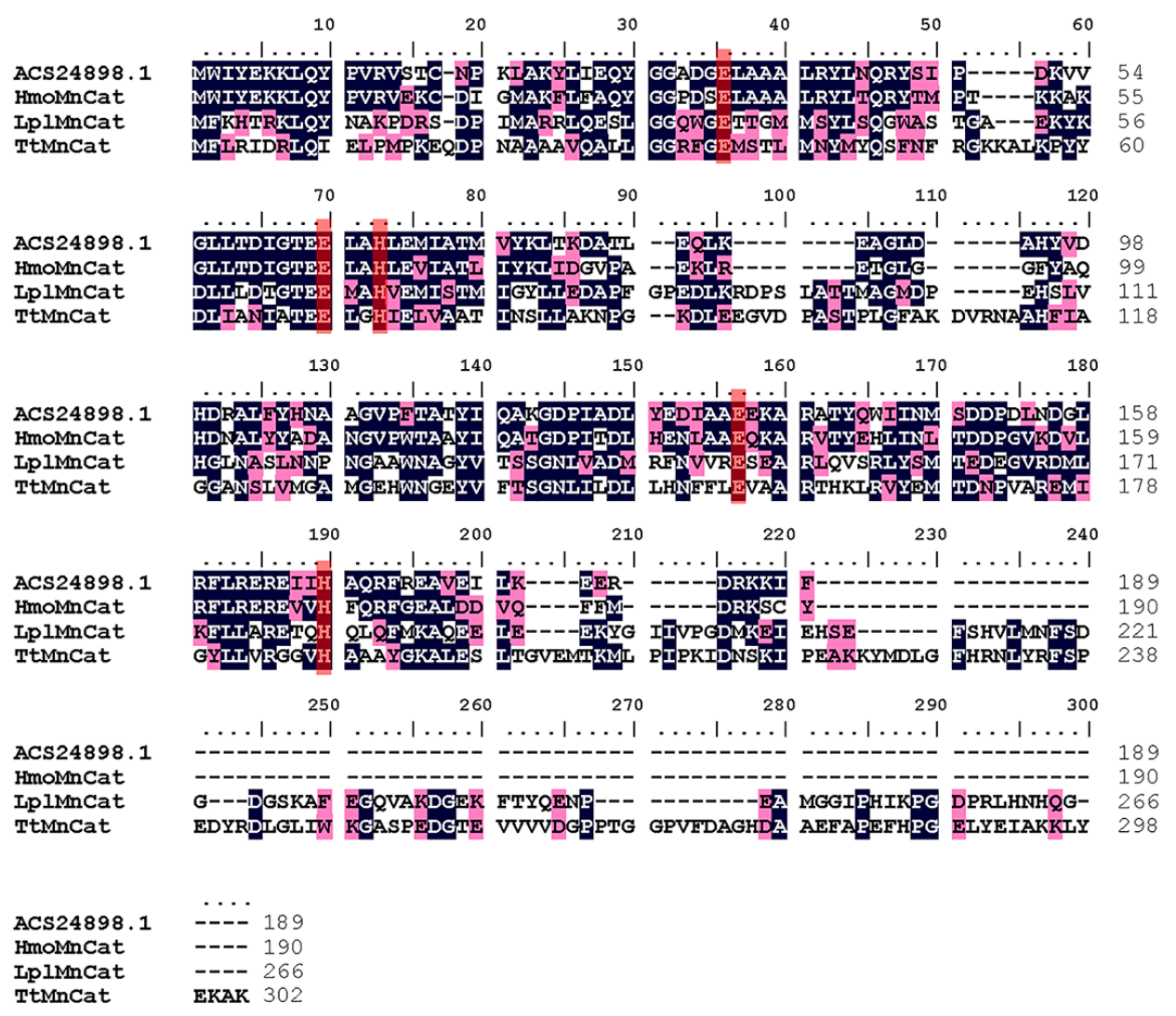

Figure 2. Multiple protein sequence alignment of Mn-catalase from Geobacillus sp. WCH70 (GWC) and three other Mn-catalases from the PeroxiBase. These sequences are HmoMnCat from Heliobacterium modesticaldum, LplMnCat from Lactobacillus plantarum (LPC), and TtMnCat from Thermus thermophiles (TTC). Identical amino acid residuals are shaded in black, and similar amino acid residuals are shaded in pink. The dimanganese clusters binding amino acids are marked with red. The multiple protein sequence alignments of GWC and three other Mn-catalases from the PeroxiBase are conducted using BioEdit 4.7.2.1.

\subsection{Gene Cloning Expression and Purification of Recombinant Enzyme}

The recombinant plasmid pET20b-MnCAT is shown in Figure S1. The size of the vector is $4178 \mathrm{bp}$. An Mn-catalase gene (588 bp) with six His tags is inserted close to the T7 promoter. After it was transformed into E. coli BL21 (DE3) pLysS cells and induced with isopropyl $\beta$-D-1-thiogalactoside (IPTG), the recombinant protein can be expressed mainly in highly soluble form with a large amount of inclusion body. As described in the Section 4.3, there are three purification steps involving multiple heat treatments and an Ni-NTA $\left(\mathrm{Ni}^{2+}\right.$ and tris(carboxymethyl) amine) Agarose column chromatograph. The purification processes are monitored by measuring the enzyme activity in combination with sodium dodecyl sulfate polyacrylamide gel electrophoresis (SDS-PAGE) in each step. The results are shown in Table 1 and Figure S2, respectively. If the activity of the crude extract is defined as 1, the activity is doubled after the first heat treatment. Correspondingly, the SDS-PAGE in Figure S2 lane 2 shows that a band between 29.0 and $20.1 \mathrm{kDa}$ is more pronounced (after the first heat treatment) than that in lane 1 (before the heat treatment). The activity further increases 17 fold after the Ni-NTA column, and the purity is greatly improved as shown in Figure S2 lane 3. Finally, after the second heat treatment, a single band appears in lane 4, indicating the homogeneity of the final enzyme. The specific activity of the final enzyme can reach $15,150 \mathrm{U} / \mathrm{mg}$ when tested at $60{ }^{\circ} \mathrm{C}$ and $\mathrm{pH}$ 8.0. It has been observed that the addition of $\mathrm{Mn}^{2+}$ in the $\mathrm{LB}$ (lysogeny broth) medium can substantially increase the targeted enzyme yield (data not shown). This observation agrees that the addition of $\mathrm{Mn}^{2+}$ helps the catalase to fold properly in E. coli cells by incorporating the ions into the active centers of 
manganese catalase [25]. The SDS-PAGE can also be used to determine the subunit molecular value. After considering the nonlinear distribution of the molecular mass in SDS-PAGE, we estimate that it is $25 \mathrm{kDa}$. However, the predicted molecular mass of the nature enzyme with a six His tags is $22.6 \mathrm{kDa}$ according to the amino acid sequence.

Table 1. Purification of recombinant enzyme from E. coli BL21 (DE3) pLysS.

\begin{tabular}{cccccc}
\hline Method & Total Activity (U) & Total Protein (mg) & $\begin{array}{c}\text { Sp Act (Specific } \\
\text { Activity) (U/mg) }\end{array}$ & $\begin{array}{c}\text { Yield } \\
\text { (\%) }\end{array}$ & $\begin{array}{c}\text { Purification } \\
\text { (fold) }\end{array}$ \\
\hline $\begin{array}{c}\text { Crude extract } \\
\text { Heat treatment } 1\end{array}$ & 116,800 & 317 & 368 & 100 & 1 \\
$\quad$ Ni-NTA & 87,200 & 128 & 681 & 75 & 2 \\
$\begin{array}{c}\left(\mathrm{Ni}^{2+} \text { and tris }\right. \\
(\text { carboxymethyl) }\end{array}$ & 62,700 & 10 & 6270 & 54 & 17 \\
Heat treatment 2 & 60,600 & 4 & 15,150 & 52 & 41 \\
\hline
\end{tabular}

\subsection{Manganese Catalase Identification}

Several manganese catalases have been reported to have a homo-hexamer structure such as LPC, TTC, and KatB [24]. In this study, we first determine the subunit molecular mass from SDS-PAGE. As shown in Figure S2 (lane 4), the molecular mass of the subunit is estimated to be $25 \mathrm{kDa}$. However, the predicted molecular mass of the subunit with a six His tags is $22.6 \mathrm{kDa}$ based on the amino acid sequence. The six His tags might contribute the increase in the molecular mass of the recombinant protein in the SDS result [32]. Next, we determine the native molecular mass from Gel permeation chromatography/ size exclusion chromatography GPC/SEC. A standard curve is constructed from four proteins with known molecular masses. As shown in Figure S3, the molecular mass of the purified catalase is calculated to be $138 \mathrm{kDa}$ (solid dot) on the curve. Therefore, the purified enzyme has six subunits per molecule, indicating that GWC is a homo-hexamer in structure. The result from inductively coupled plasma mass spectrometry (ICP-MS) shows that the purified enzyme contains $1.42 \pm 0.08$ manganese ions per subunit. To further confirm that GWC is a Mn-containing catalase, the response of GWC to cyanide has been tested. Unlike heme-containing catalases, Mn catalase is not sensitive to cyanide [18]. We have examined the residual activities of heme catalase from bovine liver and GWC in the presence of sodium cyanide. The heme catalase retains only $50 \%$ of its residual activity after $1 \mu \mathrm{M}$ cyanide treatment. In contrast, there is no observable decrease in the activity of GWC upon the treatment of $100 \mu \mathrm{M}$ cyanide. The insensitive response to cyanide inhibition is further evidence to verify that the new enzyme is a Mn-containing catalase. In addition, the new enzyme has no porphyrin Soret adsorption band (around $400 \mathrm{~nm}$ ), even when the concentration as high as $1 \mathrm{mg} / \mathrm{mL}$. The results clearly indicate that the purified enzyme GWC is a manganese catalase.

\subsection{Characteristics of Purified Recombinant Catalase GWC}

\subsection{1. $\mathrm{pH}$ Effect on Catalase Activity}

Figure 3 a shows the enzyme activity as a function of $\mathrm{pH}$ at $25^{\circ} \mathrm{C}$. The maximum activity at $\mathrm{pH} 9.0$ is defined as $100 \%$. The relative activity is below $60 \%$ when the $\mathrm{pH}$ below 6.0 and remains around $60 \%$ up to $\mathrm{pH} 11$, indicating that a weak alkaline environment is preferred. When $\mathrm{pH}<5.0$, the relative activity is under $50 \%$.

\subsubsection{Temperature Effect and Thermostability Testing}

The effect of temperature on the activity of the purified enzyme is shown in Figure $3 \mathrm{~b}$. The maximum activity at $75{ }^{\circ} \mathrm{C}$ is defined as $100 \%$. The result indicates that the activity of the catalase is below $60 \%$ when the temperature lower than $50^{\circ} \mathrm{C}$. There is a $20 \%$ activity increase when the temperature increases from $55^{\circ} \mathrm{C}$ to $60^{\circ} \mathrm{C}$. The relative activity remains above $80 \%$ between $60^{\circ} \mathrm{C}$ to $80{ }^{\circ} \mathrm{C}$. At $90{ }^{\circ} \mathrm{C}$, the activity retains above $50 \%$. Figure $3 \mathrm{c}$ shows the thermostability test of the 
catalase. The maximum activity at $0 \mathrm{~h}$ of each temperature is defined as $100 \%$. There is no observable change after incubation for $8 \mathrm{~h}$ at $70{ }^{\circ} \mathrm{C}$, and the relative activity was still above $85 \%$ after incubation for $8 \mathrm{~h}$ at $75{ }^{\circ} \mathrm{C}$. The half-life of the catalase at $80^{\circ} \mathrm{C}$ and $85^{\circ} \mathrm{C}$ is about $7.5 \mathrm{~h}$ and $3 \mathrm{~h}$, respectively. However, there is a significant drop in relative activity at $90^{\circ} \mathrm{C}$. The half-life is about $1 \mathrm{~h}$, and there was no more catalase activity after incubation at $90^{\circ} \mathrm{C}$ for $4 \mathrm{~h}$.
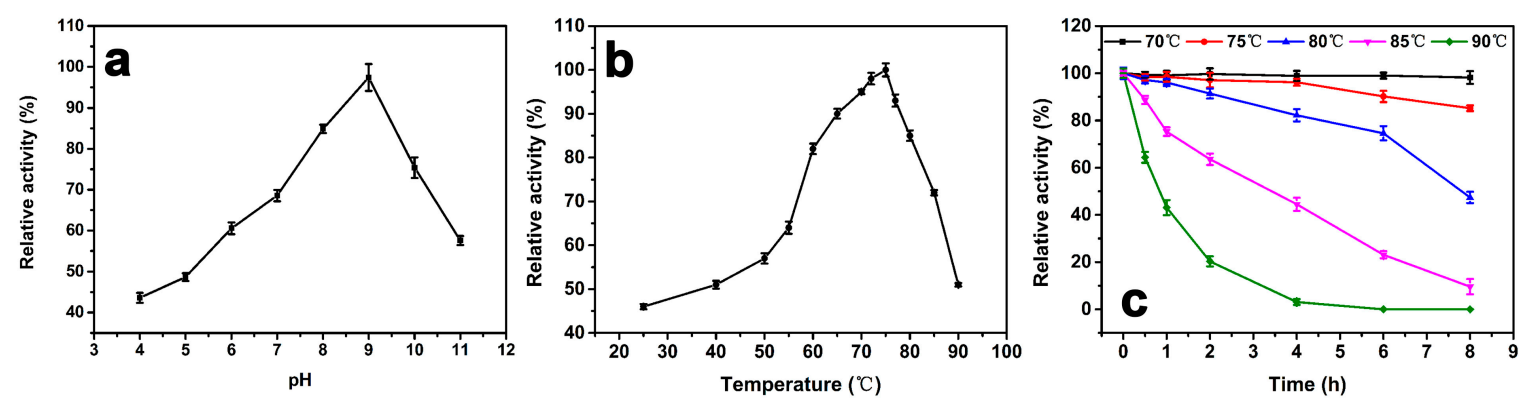

Figure 3. (a) The effect of $\mathrm{pH}$ on the relative activity of purified GWC. The assays are performed at $\mathrm{pHs}$ ranging from 4.0 to 11.0 and a temperature of $25^{\circ} \mathrm{C}$. The maximum activity at $\mathrm{pH} 9.0$ is defined as $100 \%$. (b) The effect of temperature on the relative activity of purified GWC. The assays are at $\mathrm{pH} 8.0$, and the temperatures range from $25^{\circ} \mathrm{C}$ to $90^{\circ} \mathrm{C}$. The maximum activity at $75{ }^{\circ} \mathrm{C}$ is defined as $100 \%$. (c) Thermostability test of GWC. GWC solutions at $1 \mu \mathrm{g} / \mathrm{mL}$ are pre-incubated at different temperatures ranging from $70{ }^{\circ} \mathrm{C}$ to $90{ }^{\circ} \mathrm{C}$ at $\mathrm{pH} 8.0$ for $8 \mathrm{~h}$. Then the relative activity of each sample is measured at $\mathrm{pH} 9.0$ and $75^{\circ} \mathrm{C}$. The activity prior to incubation id defined as $100 \%$ activity. The data points in the plots are expressed as the mean and standard deviation from three independent measurements.

\subsubsection{Kinetic Parameter Determination}

The kinetic parameters of the recombinant catalase are determined according to the LineweaverBurk plot method with different $\mathrm{H}_{2} \mathrm{O}_{2}$ concentrations as substrates. As shown in Figure 4, the linear regression of the plot has a correlation coefficient, $R^{2}$, of 0.9969 . The kinetic parameters $K_{m}$ and $V_{\max }$ are calculated as $67.26 \mathrm{mM}$ and $75,300 \mathrm{U} / \mathrm{mg}$, respectively. $K_{m}$ is an important characteristic of the enzyme, representing its affinity to substrates. The molecular mass of $22.6 \mathrm{kDa}$ per subunit is used to calculate $k_{\text {cat }}$ as $2.9 \times 10^{4} \mathrm{~s}^{-1}$ subunit $^{-1} . k_{\text {cat }} / K_{m}$ is calculated as $4.22 \times 10^{5} \mathrm{M}^{-1} \cdot \mathrm{s}^{-1}$.

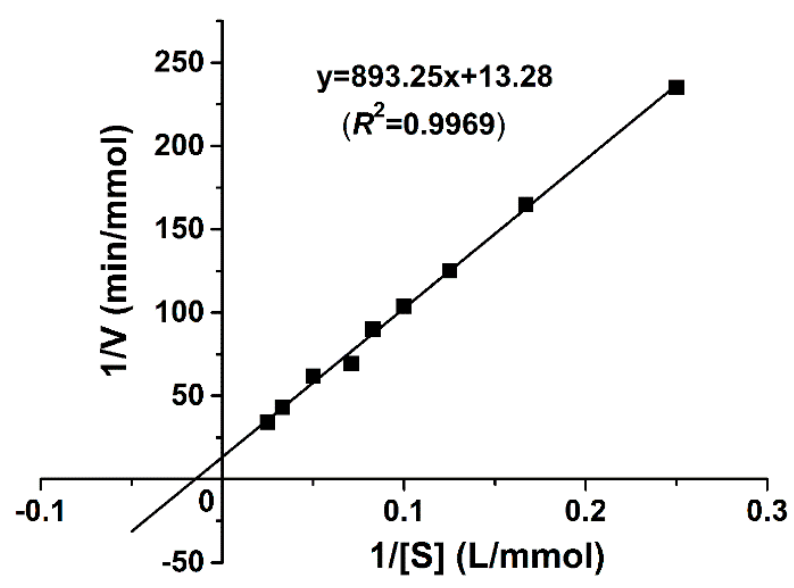

Figure 4. Lineweaver-Burk plot of purified GWC kinetics. The $y$-axis represents the reciprocal of the reaction rate and the $x$-axis is the reciprocal of the substrate concentration. The reactions were carried out at the final fixed GWC concentration of $1 \mu \mathrm{g} / \mathrm{mL}$ and various $\mathrm{H}_{2} \mathrm{O}_{2}$ substrate concentrations ranging from 4 to $40 \mathrm{mM}$ at $75{ }^{\circ} \mathrm{C}$ with $\mathrm{pH}$ 9.0. Each data point is obtained from an average of three independent kinetic measurements. The solid line is the trend-line of the linear regression, with a correlation coefficient of $R^{2}=0.9969$. 


\section{Discussion}

Normally, a catalase contains a mononuclear heme group in its active sites. Differently, a manganese catalase possesses a binuclear manganese complex in the site without an iron center. The thermostability of GWC is better than most heme catalases due to its four $\alpha$-helix bundle robust structure. The half-life of purified GWC is $7.5 \mathrm{~h}$ at $80^{\circ} \mathrm{C}$. This result is better than most heme catalases such as those from Serratia marcescens SYBC08 (90 $\left.\mathrm{min}, 60 \%, 70{ }^{\circ} \mathrm{C}\right)$ [33], Psychrobacter piscatorii T-3 $\left(15 \mathrm{~min}, 50 \%, 60^{\circ} \mathrm{C}\right)$ [34], Vibrio salmonicida $\left(10 \mathrm{~min}, 0 \%, 60^{\circ} \mathrm{C}\right)$ [35], Vibrio rumoiensis S- ${ }^{\mathrm{T}}(15 \mathrm{~min}, 0 \%$, $\left.60^{\circ} \mathrm{C}\right)$ [36], Halomonas sp. SK1 $\left(30 \mathrm{~min}, 0 \%, 55^{\circ} \mathrm{C}\right)$ [37], Psychrobacter piscatorii $\left(15 \mathrm{~min}, 20 \%, 65^{\circ} \mathrm{C}\right)$ [38], and Geobacillus sp. CHB1 (60 $\left.\mathrm{min}, 10 \%, 80^{\circ} \mathrm{C}\right)$ [14]. However, GWC is not as stable as some other Mn-catalases such as Thermus sp. YS 8-13 catalase $\left(3 \mathrm{~h}, 100 \%, 90^{\circ} \mathrm{C}\right)$ and P. calidifontis VA1 catalase ( $432 \mathrm{~min}, 50 \%, 90^{\circ} \mathrm{C}$ ). The peptide chain of GWC (189 amino acids) is shorter than those of previously reported manganese catalases such as LPC (266 amino acides), TTC (302 amino acides), Thermus sp. YS 8-13 catalase ( 302 amino acids), and P. calidifontis VA1 catalase (298 amino acids) from NCBI GenBank. Unlike most manganese catalases, GWC has no C-terminal tail revealed by SWISS-MODEL. Hydrogen bonds and salt bridges are the main forces of its homo-hexamer assembly, and a loss of the C-terminal tail contributes to smaller number of hydrogen bonds and salt bridges [24]. Moreover, the $\mathrm{Ca}^{2+}$ binding site in the C-terminal tail may stabilize the homo-hexamer structure [24]. Therefore, the homo-hexamer structure of GWC may not be as stable as that of other manganese catalases from Thermus sp. YS 8-13 or $P$. calidifontis VA1. We suggest that this is the reason why GWC quickly became inactive above $90^{\circ} \mathrm{C}$. Nevertheless, compared to most heme catalases mentioned above, GWC shows better thermo-stability due to the four $\alpha$-helix bundle structure of its subunit [18].

In the present study, the manganese content is $1.42 \pm 0.08$ ions per subunit of Mn-catalase, as determined by ICP-MS. This value is close to those for other manganese catalases in previous studies such as $1.12 \pm 0.37$ atoms/subunit (Lactobacillus plantarum [19]), 1.2 atoms/subunit (Thermus sp. YS 8-13 [21]), $1.4 \pm 0.4$ atoms/subunit (Thermoleophilum album [22]), and $1.32 \pm 0.03$ atoms/subunit (Pyrobaculum caldifontis VA1 [23]). These values are lower than crystal structure data (two manganese atoms/subunit), which could be due to a loss of manganese ions during purification [23]. The native molecular mass is $138 \mathrm{kDa}$ according to GPC/SEC, and the molecular mass of one subunit is $22.6 \mathrm{kDa}$. Therefore, the catalase is supposed to be a homo-hexamer enzyme like manganese catalases from Lactobacillus plantarum [19], Thermus thermophiles [20], Thermus sp. YS 8-13 [21], and Anabaena PCC7120 [24]. Kinetic analysis of GWC shows a $K_{m}$ value of $67.26 \mathrm{mM}$ and a $k_{\text {cat }}$ value of $2.9 \times 10^{4} \mathrm{~s}^{-1}$ subunit ${ }^{-1}$ toward $\mathrm{H}_{2} \mathrm{O}_{2}$. The kinetic parameters are comparable to the previously reported manganese catalases, as Table 2 shows.

Table 2. The kinetic parameters of GWC compared with those of other characterized Mn-catalases.

\begin{tabular}{|c|c|c|c|c|}
\hline Mn-Catalase & $\begin{array}{c}k_{\text {cat }} \\
\left(\mathrm{s}^{-1} \cdot \text { subunit }^{-1}\right)\end{array}$ & $K_{m}(\mathrm{mM})$ & $\begin{array}{c}k_{\mathrm{cat}} / K_{m} \\
\left(\mathrm{M}^{-1} \mathrm{~s}^{-1}\right)\end{array}$ & Reference \\
\hline Lactobacillus plantarum & $3.3 \times 10^{4}$ & 350 & $9.4 \times 10^{4}$ & [19] \\
\hline Thermus thermophiles & $2.6 \times 10^{5}$ & 83 & $3.1 \times 10^{6}$ & [20] \\
\hline Thermoleophilum album & $6.2 \times 10^{3}$ & 15 & $4.1 \times 10^{5}$ & [22] \\
\hline Pyrobaculum caldifontis & $2.9 \times 10^{4}$ & 170 & $1.7 \times 10^{5}$ & [23] \\
\hline Anabaena PCC7120 & $2.23 \times 10^{4}$ & 1.63 & $1.35 \times 10^{7}$ & [24] \\
\hline Thermomicrobium roseum & $2.02 \times 10^{4}$ & 20 & $1.01 \times 10^{6}$ & [25] \\
\hline Geobacillus sp. WCH70 & $2.9 \times 10^{4}$ & 67.26 & $4.22 \times 10^{5}$ & This work \\
\hline
\end{tabular}

\section{Materials and Methods}

\subsection{Amino Acid Sequences Analysis}

We examined the phylogenetic relationships of ACS24898.1 compared with other bacterial or archaea manganese catalases. The protein sequences were obtained from the PeroxiBase. The relationships of the sequences were built using MEGA 7.0.25 (Pennsylvania State University, 
State College, PA, USA). The trees were constructed by the neighbor-joining method. The test of inferred phylogeny was bootstrapped for 1000 replications. The multiple protein sequence alignments of GWC and three other Mn-catalases from the PeroxiBase were conducted using BioEdit 4.7.2.1 (Isis Pharmaceuticals, Inc., Carlsbad, CA, USA). These sequences were HmoMnCat from Heliobacterium modesticaldum, LplMnCat from Lactobacillus plantarum (LPC), and TtMnCat from Thermus thermophiles (TTC).

\subsection{Expression Vector Construction}

The Geobacillus sp. WCH70 [31] in freeze-dried form was purchased from the China Center of Industrial Culture Collection (CICC) (Beijing, China). The culture was aerobically grown in $50 \mathrm{~mL}$ medium containing $5 \mathrm{~g}$ tryptone, $3 \mathrm{~g}$ beef extract, and $5 \mathrm{~g} \mathrm{NaCl}$ (Sinopharm Chemical Reagent Co., Ltd., Beijing, China) per liter at $\mathrm{pH} 7.5$ and $70{ }^{\circ} \mathrm{C}$, with shaking at $180 \mathrm{rpm}$ for $18 \mathrm{~h}$. The genome of Geobacillus sp. WCH70 was extracted by a Rapid Bacterial Genomic DNA Isolation Kit (Sangon Biotech, Shanghai, China). It was used as a Polymerase Chain Reaction (PCR) template. The catalase gene from Geobacillus sp. WCH70 was amplified by PCR with Ex Taq ${ }^{\circledR}$ (TaKaRa, Dalian, China) and primers (forward primer: 5'-GGAATTCCATATGTGGATTTATGAAA-AAAAATTGCAATAT-3' and reverse primer: $5^{\prime}$-CCGCTCGAGTTAGTGATGGTGATGGTG-ATGAAAAATTTTCTTGCG-3'). $5^{\prime}$-GGAATTC-3' and $5^{\prime}$-CCG-3' $3^{\prime}$ were protective bases. $5^{\prime}$-CATATG-3' and $5^{\prime}$-CTCGAG-3' represented the Nde I and Xho I restriction enzyme cutting sites. We introduced a His-tag sequence (5'-GTGATGGTGATGGTGATG-3') in the reverse primer. The primers were designed using Primer 5.0. The PCR program was set as follows: denaturing $\left(5 \mathrm{~min}, 95^{\circ} \mathrm{C}\right)$, followed by 30 cycles of denaturing $\left(30 \mathrm{~s}, 95^{\circ} \mathrm{C}\right)$, annealing $\left(30 \mathrm{~s}, 55^{\circ} \mathrm{C}\right)$, polymerization $\left(1 \mathrm{~min}, 72{ }^{\circ} \mathrm{C}\right)$, and final polymerization $(10 \mathrm{~min}$, $72{ }^{\circ} \mathrm{C}$ ). The expression vector pET20b (TaKaRa, Dalian, China) and the PCR product were digested separately with the restriction enzymes Nde I and Xho I (TaKaRa, Dalian, China). The digested product was ligated with $\mathrm{T}_{4}$ DNA ligase (TaKaRa, Dalian, China) after agarose gel purification. At last, the recombinant plasmid was transformed into E. coli BL21 (DE3) pLysS (Novagen, Madison, WI, USA). The catalase sequence was confirmed by Sangon Biotech (Shanghai, China). For seeding cell preparation, the recombinant strains were cultured in $50 \mathrm{~mL}$ LB medium (10 g tryptone (Oxoid, UK), $5 \mathrm{~g}$ yeast extract (Oxoid, $\mathrm{UK}$ ) and $10 \mathrm{~g} \mathrm{NaCl}$ per liter, at $\mathrm{pH}$ 7.0) with $50 \mu \mathrm{g} / \mathrm{mL}$ ampicillin and $34 \mathrm{\mu g} / \mathrm{mL}$ chloramphenicol (Sigma, St. Louis, MO, USA).

\subsection{Expression and Purification of Recombinant Enzyme}

The recombinant strains from above were cultured in $2 \mathrm{~L} \mathrm{LB}$ medium, with a $\mathrm{Mn}^{2+}$ concentration of $100 \mu \mathrm{M}$, and grown at $37^{\circ} \mathrm{C}$, with shaking at $180 \mathrm{rpm}$. When $\mathrm{OD}_{600}$ reached 1.8 , a solution of isopropyl $\beta$-D-1-thiogalactoside (IPTG) was added into the culture to a final concentration of $0.5 \mathrm{mM}$. Then the culture continued growing at $28{ }^{\circ} \mathrm{C}$, with shaking at $120 \mathrm{rpm}$ for $16 \mathrm{~h}$. The cells were harvested by centrifugation at $8000 \times g$ for $10 \mathrm{~min}$ and suspended in Tris- $\mathrm{HCl}(20 \mathrm{mM}, \mathrm{pH} 8.0)$ buffer. The suspended cells were lysed by ultrasonication and centrifuged a second time at $18,000 \times g$ for $10 \mathrm{~min}$ to remove cell walls. The supernatant was incubated at $60{ }^{\circ} \mathrm{C}$ for $30 \mathrm{~min}$ then centrifuged again at $18,000 \times g$ for $10 \mathrm{~min}$ to remove most heat-labile proteins. The new supernatant was loaded on a Ni-NTA Agarose column (Cube Biotech, Monheim am Rhein, Germany). The column was first washed with $20 \mathrm{mM}$ Tris- $\mathrm{HCl}$ ( $\mathrm{pH}$ 8.0) buffer to remove impurities until the absorbance at $280 \mathrm{~nm}$ was not detectable by NanoDrop 2000C (Thermo Fisher, Waltham, MA, USA). The column then was eluted with the same buffer but containing $100 \mathrm{mM}$ imidazole. The elution was collected when the absorbance at $280 \mathrm{~nm}$ appeared. The collected solution was dialyzed (MW 3000) against $20 \mathrm{mM}$ Tris- $\mathrm{HCl}$ (pH 8.0) buffer three times. Finally, the retentate was incubated at $70{ }^{\circ} \mathrm{C}$ for $1 \mathrm{~h}$ and then centrifuged at $18,000 \times g$ for $10 \mathrm{~min}$. The collected supernatant was ready for analysis. The protein purity was determined by 15\% SDS-PAGE (BIO-RAD, Hercules, CA, USA) gel electrophoresis [39], and the concentration was measured by Bradford assay using a standard protein curve constructed from eight concentrations of bovine serum albumin (BSA) [40]. 


\subsection{Metal Analysis and Molecular Size Determination}

The purified enzyme was diluted to $50 \mu \mathrm{g} / \mathrm{mL}$ in $20 \mathrm{mM}$ at pH 7.0 in Tris- $\mathrm{HCl}$ buffer and analyzed for Mn ions using inductively coupled plasma mass spectrometry (ICP-MS) (HR-ICP-MS, Thermo Fisher, Waltham, MA, USA). The native protein size was determined using a Bio-Gel SEC 40-XL size-exclusion column (Bio-Rad, Hercules, CA, USA), $300 \times 7.8 \mathrm{~mm}$, eluted with potassium phosphate buffer $(20 \mathrm{mM}, \mathrm{pH} 7.0)$ at a flow rate of $0.5 \mathrm{~mL} / \mathrm{min}$ controlled by a Viscotek 270 GPC/SEC system (Malvern, Malvern, UK). The standard molecular size curve was constructed by conalbumin $(75 \mathrm{kDa})$, aldolase (158 kDa), ferritin (440 kDa), and thyroglobulin (669 kDa). SDS-PAGE was used to determine the molecular mass of the subunit. We also tested sodium cyanide (the final concentration was $100 \mu \mathrm{M}$ and $1 \mu \mathrm{M}$ ) for an inhibiting effect on the purified protein and bovine liver (Sigma, St. Louis, MO, USA).

\subsection{Enzyme Activity Characterization}

The activity of the purified enzyme was tested with substrates and $\mathrm{H}_{2} \mathrm{O}_{2}$. The activity assay was performed according to Beers Jr. and Sizer [41]. The reaction was monitored at $240 \mathrm{~nm}$ $\left(\varepsilon_{240}=43.6 \mathrm{M}^{-1} \mathrm{~cm}^{-1}\right)$ of the $\mathrm{H}_{2} \mathrm{O}_{2}$ adsorption peak [42] using a UV-2700 spectrophotometer (Shimadzu, Kyoto, Japan). The purified catalase was diluted to a concentration of about $1 \mu \mathrm{g} / \mathrm{mL}$ by Tris- $\mathrm{HCl}(20 \mathrm{mM}, \mathrm{pH} 8.0)$ buffer, and the $\mathrm{H}_{2} \mathrm{O}_{2}$ was diluted to $20 \mathrm{mM}$ with various $\mathrm{pH}$ buffers. Then $50 \mu \mathrm{L}$ enzyme solution was mixed with $950 \mu \mathrm{L} \mathrm{H}_{2} \mathrm{O}_{2}$ solution at specified temperatures controlled by a water bath. The reaction was monitored for $1 \mathrm{~min}$. One unit of catalase activity was defined as the amount of enzyme required to convert $1 \mu \mathrm{mol}$ of $\mathrm{H}_{2} \mathrm{O}_{2}$ to $\mathrm{H}_{2} \mathrm{O}$ and $\mathrm{O}_{2}$ per min. Each measurement was conducted three times. To study the effect of $\mathrm{pH}$ on the activity, the $\mathrm{H}_{2} \mathrm{O}_{2}$ was diluted with citrate buffer ( $\mathrm{pH} 4.0,5.0$, and 6.0), Tris-HCl buffer ( $\mathrm{pH} 7.0,8.0$, and 9.0), or Gly-NaOH buffer ( $\mathrm{pH} 10.0$ and 11.0). The reaction was kept at $25^{\circ} \mathrm{C}$. The optimum temperature assay was performed at $\mathrm{pH} 8.0$ in $20 \mathrm{mM}$ Tris-HCl buffer. The enzyme solution was pre-incubated and kept at different temperatures ranging from $25^{\circ} \mathrm{C}$ to $90{ }^{\circ} \mathrm{C}$. To assay the enzyme thermostability, $20 \mu \mathrm{g} / \mathrm{mL}$ diluted enzyme was incubated at $60^{\circ} \mathrm{C}, 70{ }^{\circ} \mathrm{C}, 80^{\circ} \mathrm{C}, 85^{\circ} \mathrm{C}$, and $90{ }^{\circ} \mathrm{C}$ for $8 \mathrm{~h}$. During the incubation, samples were collected at different time pointes for the activity assay. Then the relative activity of each sample was measured at $75^{\circ} \mathrm{C}$ at $\mathrm{pH}$ of 9.0 in $20 \mathrm{mM}$ Tris- $\mathrm{HCl}$ buffer. For a kinetic study, the purified enzyme at a fixed final concentration of $1 \mu \mathrm{g} / \mathrm{mL}$ reacted with $\mathrm{H}_{2} \mathrm{O}_{2}$ at different concentrations ranging from 4 to $40 \mathrm{mM}$ at $75{ }^{\circ} \mathrm{C}$ and $\mathrm{pH}$ 9.0. The reaction was monitored at the $\mathrm{H}_{2} \mathrm{O}_{2}$ characteristic absorption peak of $240 \mathrm{~nm}$ for $1 \mathrm{~min}$. The change in the substrate concentrations over time was recorded. Each reaction was duplicated three times. An average reaction velocity (rate) was calculated from each kinetic curve. A Lineweaver-Burk plot (double-reciprocal plot) was constructed using the reciprocal of the rate as the $y$-axis and the reciprocal of the substrate concentration as the $x$-axis. The kinetic parameter of the maximum reaction velocity, $V_{\max }$, was calculated from the inverse of the y-intercept and $K_{m}$, the substrate concentration at half the reaction rate, from the slope of the plot according to Lineweaver and Burk [43].

\section{Conclusions}

In this paper, we successfully cloned the Mn-catalase gene from Geobacillus sp. WCH70 and then expressed it in E. coli BL21 (DE3) pLysS cells for the first time. We have purified and characterized the enzyme and identified it as a new thermophilic manganese catalase (GWC). It possesses the smallest subunit $(22.6 \mathrm{kDa})$ compared with the other reported manganese catalases. The maximum specific activity of GWC is $75,300 \mathrm{U} / \mathrm{mg}$ at $75{ }^{\circ} \mathrm{C}$ and $\mathrm{pH}$ 9.0. The catalase shows high activity over the temperature range from 60 to $80^{\circ} \mathrm{C}$. In addition, the catalase shows high activity in weak alkaline environments, with a maximum at $\mathrm{pH}$ 9.0. The results suggest that this new manganese catalase is promising in the textile, paper-making, and other industries for removing $\mathrm{H}_{2} \mathrm{O}_{2}$. 
Supplementary Materials: The following are available online at www.mdpi.com/2073-4344/7/9/277/s1, Figure S1: Recombinant plasmid of pET20b-MnCAT map, Figure S2: Coomassie-blue stained SDS-PAGE gel of the enzyme, and Figure S3: Gel filtration analysis of purified GWC.

Acknowledgments: The authors are grateful for the financial support from the National Natural Science Foundation of China (Grant Numbers: 31670797).

Author Contributions: Hai-Chao $\mathrm{Li}$ and Zheng-Qiang $\mathrm{Li}$ conceived and designed the experiments; Qing Yu and Xin-Yu Cao performed the experiments; Hui Wang analyzed the data; Li Ma contributed reagents/materials/analysis tools; and Hai-Chao Li wrote the paper.

Conflicts of Interest: The authors declare no conflicts of interest.

\section{References}

1. Oscar, L.; Oscar, C.B. Physiological Studies of Connecticut Leaf Tobacco; United States Department of Agriculture: Washington, DC, USA, 1900; Volume 56, pp. 5-57.

2. Qin, J.; Lu, M.-X.; Zheng, Y.-T.; Du, Y.-Z. Molecular cloning, characterization, and functional analysis of catalase in Frankliniella occidentalis (Thysanoptera: Thripidae). Ann. Entomol. Soc. Am. 2017, 110, $212-220$.

3. Wang, H.-X.; Tokusige, Y.; Shinoyama, H.; Fujii, T.; Urakami, T. Purification and characterization of a thermostable catalase from culture broth of Thermoascus aurantiacus. J. Ferment. Bioeng. 1998, 85, 169-173. [CrossRef]

4. Sharif, A.; Ashraf, M.; Javeed, A.; Anjum, A.A.; Akhtar, M.F.; Akhtar, B.; Saleem, A. Oxidative stress responses in Wistar rats on subacute exposure to pharmaceutical wastewater. Environ. Sci. Pollut. Res. 2016, 23, 24158-24165. [CrossRef] [PubMed]

5. Zeng, H.-W.; Cai, Y.-J.; Liao, X.-R.; Qian, S.-L.; Zhang, F.; Zhang, D.-B. Optimization of catalase production and purification and characterization of a novel cold-adapted Cat-2 from mesophilic bacterium Serratia marcescens SYBC-01. Ann. Microbiol. 2010, 60, 701-708. [CrossRef]

6. Paar, A.; Costa, S.; Tzanov, T.; Gudelj, M.; Robra, K.H.; Cavaco-Paulo, A.; Gübitz, G.M. Thermo-alkali-stable catalases from newly isolated Bacillus sp. for the treatment and recycling of textile bleaching effluents. J. Biotechnol. 2001, 89, 147-153. [CrossRef]

7. Tzanov, T.; Costa, S.; Guebitz, G.M.; Cavaco-Paulo, A. Dyeing in catalase-treated bleaching baths. Color. Technol. 2010, 117, 1-5. [CrossRef]

8. Fu, X.-H.; Wang, W.; Hao, J.-H.; Zhu, X.-L.; Sun, M. Purification and characterization of catalase from marine bacterium Acinetobacter sp. YS0810. BioMed Res. Int. 2014, 2014, 409626. [CrossRef] [PubMed]

9. Josef, D.; Wolfgang, S. The mechanism of hydrogen peroxide bleaching. Text. Chem. Color. 1996, 28, 24-28.

10. Chelikani, P.; Fita, I.; Loewen, P.C. Diversity of structures and properties among catalases. Cell. Mol. Life Sci. 2004, 61, 192-208. [CrossRef] [PubMed]

11. Grigoras, A.G. Catalase immobilization-A review. Biochem. Eng. J. 2017, 117, 1-20. [CrossRef]

12. Pradhan, A.; Herrero-de-Dios, C.; Belmonte, R.; Budge, S.; Garcia, A.L.; Kolmogorova, A.; Lee, K.K.; Martin, B.D.; Ribeiro, A.; Bebes, A.; et al. Elevated catalase expression in a fungal pathogen is a double-edged sword of iron. PLoS Pathog. 2017, 13, e1006405. [CrossRef] [PubMed]

13. Switala, J.; Loewen, P.C. Diversity of properties among catalases. Arch. Biochem. Biophys. 2002, 401, $145-154$. [CrossRef]

14. Jia, X.-B.; Chen, J.-C.; Lin, C.-Q.; Lin, X.-J. Cloning, expression, and characterization of a novel thermophilic monofunctional catalase from Geobacillus sp. CHB1. BioMed Res. Int. 2016, 2016, 7535604. [CrossRef] [PubMed]

15. Thompson, V.S.; Schaller, K.D.; Apel, W.A. Purification and characterization of a novel thermo-alkali-stable catalase from Thermus brockianus. Biotechnol. Prog. 2003, 19, 1292-1299. [CrossRef] [PubMed]

16. Ebara, S.; Shigemori, Y. Alkali-tolerant high-activity catalase from a thermophilic bacterium and its overexpression in Escherichia coli. Protein Expr. Purif. 2008, 57, 255-260. [CrossRef] [PubMed]

17. Yu, Z.-X.; Zheng, H.-C.; Zhao, X.-Y.; Li, S.-F.; Xu, J.-Y.; Song, H. High level extracellular production of a recombinant alkaline catalase in E. coli BL21 under ethanol stress and its application in hydrogen peroxide removal after cotton fabrics bleaching. Bioresour. Technol. 2016, 214, 303-310. [CrossRef] [PubMed]

18. Whittaker, J.W. Non-heme manganese catalase-The 'other' catalase. Arch. Biochem. Biophys. 2011, 525, 111-120. [CrossRef] [PubMed] 
19. Kono, Y.; Fridovich, I. Isolation and characterization of the pseudocatalase of Lactobacillus plantarum. J. Biol. Chem. 1983, 258, 6015-6019. [PubMed]

20. Barynin, V.V.; Grebenko, A.I. T-catalase is a nonheme catalase of the extremally thermophilic bacterium Thermus thermophilus HB8. Dokl. Akad. Nauk SSSR 1986, 286, 461-464.

21. Kagawa, M.; Murakoshi, N.; Nishikawa, Y.; Matsumoto, G.; Kurata, Y.; Mizobata, T.; Kawata, Y.; Nagai, J. Purification and cloning of a thermostable manganese catalase from a thermophilic bacterium. Arch. Biochem. Biophys. 1999, 362, 346-355. [CrossRef] [PubMed]

22. Allgood, G.S.; Perry, J.J. Characterization of a manganese-containing catalase from the obligate thermophile Thermoleophilum album. J. Bacteriol. 1986, 168, 563-567. [CrossRef] [PubMed]

23. Amo, T.; Atomi, H.; Imanaka, T. Unique presence of a manganese catalase in a hyperthermophilic archaeon, Pyrobaculum calidifontis VA1. J. Bacteriol. 2002, 184, 3305-3312. [CrossRef] [PubMed]

24. Bihani, S.C.; Chakravarty, D.; Ballal, A. KatB, a cyanobacterial Mn-catalase with unique active site configuration: Implications for enzyme function. Free Radic. Biol. Med. 2016, 93, 118-129. [CrossRef] [PubMed]

25. Baginski, R.; Sommerhalter, M. A manganese catalase from Thermomicrobium roseum with peroxidase and catecholase activity. Extremophiles 2016, 21, 201-210. [CrossRef] [PubMed]

26. Shi, X.-L.; Feng, M.-Q.; Zhao, Y.-J.; Guo, X.; Zhou, P. Overexpression, purification and characterization of a recombinant secretary catalase from Bacillus subtilis. Biotechnol. Lett. 2008, 30, 181-186. [CrossRef] [PubMed]

27. Shi, X.-L.; Feng, M.-Q.; Shi, J.; Shi, Z.-H.; Zhong, J.; Zhou, P. High-level expression and purification of recombinant human catalase in Pichia pastoris. Protein Expr. Purif. 2007, 54, 24-29. [CrossRef] [PubMed]

28. Gellissen, G.; Piontek, M.; Dahlems, U.; Jenzelewski, V.; Gavagan, J.E.; Dicosimo, R.; Anton, D.L.; Janowicz, Z.A. Recombinant Hansenula polymorpha as a biocatalyst: Coexpression of the spinach glycolate oxidase (GO) and the S. cerevisiae catalase T (CTT1) gene. Appl. Microbiol. Biotechnol. 1996, 46, 46-54. [CrossRef] [PubMed]

29. Rochat, T.; Miyoshi, A.; Gratadoux, J.J.; Duwat, P.; Sourice, S.; Azevedo, V.; Langella, P. High-level resistance to oxidative stress in Lactococcus lactis conferred by Bacillus subtilis catalase KatE. Microbiology 2005, 151, 3011-3018. [CrossRef] [PubMed]

30. Hidalgo, A.; Betancor, L.; Moreno, R.; Zafra, O.; Cava, F.; Fernández-Lafuente, R.; Guisán, J.M.; Berenguer, J. Thermus thermophilus as a cell factory for the production of a thermophilic Mn-dependent catalase which fails to be synthesized in an active form in Escherichia coli. Appl. Environ. Microbiol. 2004, 70, 3839-3844. [CrossRef] [PubMed]

31. Brumm, P.J.; Land, M.L.; Mead, D.A. Complete genome sequences of Geobacillus sp. WCH70, a thermophilic strain isolated from wood compost. Stand. Genom. Sci. 2016, 11. [CrossRef] [PubMed]

32. Zhong, Y.-B.; Zhang, X.-H.; Chen, J.-X.; Chi, Z.-H.; Sun, B.-G.; Li, Y.; Austin, B. Overexpression, purification, characterization, and pathogenicity of Vibrio harveyi hemolysin VHH. Infect. Immun. 2006, 74, 6001-6005. [CrossRef] [PubMed]

33. Zeng, H.-W.; Cai, Y.-J.; Liao, X.-R.; Zhang, F.; Zhang, D.-B. Production, characterization, cloning and sequence analysis of a monofunctional catalase from Serratia marcescens SYBC08. J. Basic Microbiol. 2011, 51, 205-214. [CrossRef] [PubMed]

34. Kimoto, H.; Yoshimune, K.; Matsuyma, H.; Yumoto, I. Characterization of catalase from psychrotolerant Psychrobacter piscatorii T-3 exhibiting high catalase activity. Int. J. Mol. Sci. 2012, 13, 1733-1746. [CrossRef] [PubMed]

35. Lorentzen, M.S.; Moe, E.; Jouve, H.M.; Willassen, N.P. Cold adapted features of Vibrio salmonicida catalase: Characterisation and comparison to the mesophilic counterpart from Proteus mirabilis. Extremophiles 2006, 10, 427-440. [CrossRef] [PubMed]

36. Yumoto, I.; Ichihashi, D.; Iwata, H.; Istokovics, A.; Ichise, N.; Matsuyama, H.; Okuyama, H.; Kawasaki, K. Purification and characterization of a catalase from the facultatively psychrophilic bacterium Vibrio rumoiensis S-1 ${ }^{\mathrm{T}}$ exhibiting high catalase activity. J. Bacteriol. 2000, 182, 1903-1909. [CrossRef] [PubMed]

37. Phucharoen, K.; Hoshino, K.; Takenaka, Y.; Shinozawa, T. Purification, characterization, and gene sequencing of a catalase from an alkali- and halo-tolerant bacterium, Halomonas sp. SK1. Biosci. Biotechnol. Biochem. 2002, 66, 955-962. [CrossRef] [PubMed]

38. Wang, W.; Sun, M.; Liu, W.-S.; Zhang, B. Purification and characterization of a psychrophilic catalase from Antarctic Bacillus. Can. J. Microbiol. 2008, 54, 823-828. [CrossRef] [PubMed] 
39. Laemmli, U.K. Cleavage of structural proteins during the assembly of the head of bacteriophage T4. Nature 1970, 227, 680-685. [CrossRef] [PubMed]

40. Bradford, M.M. A rapid and sensitive method for the quantitation of microgram quantities of protein utilizing the principle of protein-dye binding. Anal. Biochem. 1976, 72, 248-254. [CrossRef]

41. Beers, R.F.; Sizer, I.W. A spectrophotometric method for measuring the breakdown of hydrogen peroxide by catalase. J. Biol. Chem. 1952, 195, 133-140. [PubMed]

42. Hildebrandt, A.G.; Roots, I. Reduced nicotinamide adenine dinucleotide phosphate (NADPH)-dependent formation and breakdown of hydrogen peroxide during mixed function oxidation reactions in liver microsomes. Arch. Biochem. Biophys. 1975, 171, 385-397. [CrossRef]

43. Lineweaver, H.; Burk, D. The determination of enzyme dissociation constants. J. Am. Chem. Soc. 1934, 56, 658-666. [CrossRef]

(C) 2017 by the authors. Licensee MDPI, Basel, Switzerland. This article is an open access article distributed under the terms and conditions of the Creative Commons Attribution (CC BY) license (http://creativecommons.org/licenses/by/4.0/). 